\title{
Identification of regions in need of crisis management using the example of the dairy industry
}

\author{
Mikhail Chernyakov ${ }^{1, *}$, Maria Chernyakova $^{2}$, Irina Chernyakova ${ }^{1,2}$ and Galina Gritsenko ${ }^{3}$ \\ ${ }^{1}$ Novosibirsk State Technical University, 20, Karl Marx Ave., 630078, Novosibirsk, Russia \\ ${ }^{2}$ Siberian Institute of Management - Branch of Russian Academy of National Economy and State \\ Service Under the RF President, 6, Nizhnegorskaya, 630102, Novosibirsk, Russia \\ ${ }^{3}$ Federal state budgetary institution of science of the Siberian Federal scientific center of \\ agrobiotechnology the Russian Academy of Sciences (RAS CPNCA), Altai laboratory Sibniieskh
}

\begin{abstract}
In order to determine the depressed regions of the status of the dairy industry, the main target functions of the anti-crisis strategy are formulated. As a preliminary research method in crisis management, a morphological analysis was chosen, which is an effective methodological approach. The advantages and disadvantages of morphological analysis are evaluated. A morphological matrix for ranking the regions of Siberia according to the main indicators of the dairy industry was built and 5 clusters of regional status were formed. Only one region was classified as depressed - the Republic of Tuva. Effective anti-crisis management tools are proposed. The introduction of digital technologies and the organization of automated workstations on their basis are recommended, which will compensate for the shortage of qualified personnel, increase labor productivity, and government support for these events and the attraction of investors are also required.
\end{abstract}

\section{Introduction}

The possibility of a crisis in organizations of dairy industries exists at any time, even when no obvious signs of such a process are manifested. This is due to the fact that in the management process there is a constant risk associated with the cyclical development of the socio-economic system, as well as the proportionality and dynamism of managed and unmanaged processes. Human needs and interests are also changing dynamically. "That is why the management of any system of a socio-economic nature" [1] should always be, to one extent or another, anti-crisis.

Both Russian [2-5] and foreign researchers [6-10] paid attention to the tasks of the anticrisis management of the dairy industry.

Anastasia Babkina [2-3] «on example of two agrarian dairy enterprises of Vyazmy Region Smolensk Oblast there was drawn estimation of operation research method expediency to harmonize investment business plan and sectoral crisis management

\footnotetext{
* Corresponding author: mkacadem@mail.ru
} 
program. It was proved the method is cost saving technique reduces negative profits comparable with sums of budgetary subsidy for business units to develop dairy stockbreeding within backing of regional goal-oriented program of agriculture advancement».

Research by Don J Deasy showed that 'the dairy industry is under pressure to improve product security, implement efficient risk management and rapid response capabilities, and manage quality 'from trough to table' to achieve full, verifiable traceability. In order to invest proactively in the future of the industry, individual processors must reassess their handling of quality and traceability data for strategic and competitive success, make appropriate physical configuration and operational adjustments, and deploy readily available technological tools to meet legislative and consumer demands, enhance product quality and increase operational efficiency and profits" [6].

The aim of the research by Agatha Popescu [7] was to analyze the main trends in the milk market and the impact of the dairy crisis in Romania for the period 2007-2015. At that time the number of cattle decreased as a result of the high price of agricultural resources and the low price of milk in farms. Unskimmed milk production decreased by $15 \%$, and cow's milk by $21.3 \%$. Due to a shortage of raw milk, processers were forced to purchase raw milk from other countries. "The weak connection between producers-processorstraders and consumers along milk chain have allowed milk crisis to leave deep traces and claimed a change in milk market policy regarding more equitable measures and tools for milk producers, taking into account the expenses for production factors as well as consumer price, in order to avoid production concentration and to assure a balanced distribution of value added along milk chain. The strong competition among farms, oblige farmers to pay more attention to knowledge, training level, modern technologies, and farm management, factors which could keep production cost at a low level, assure a high milk quality, and economic efficiency" [7].

The very possibility of implementing crisis management is determined, first of all, by the human factor. Rational economic behavior of a person enables searching for ways out of the current crisis, directing efforts to solve the most acute problems, while applying the experience gained in the past to overcome problem situations [4].

As a result of a thorough analysis of the industry strategy, regional administrations should focus on the following five aspects (Fig. 1), which are the basic target fictions in the development of the anti-crisis strategy [10].

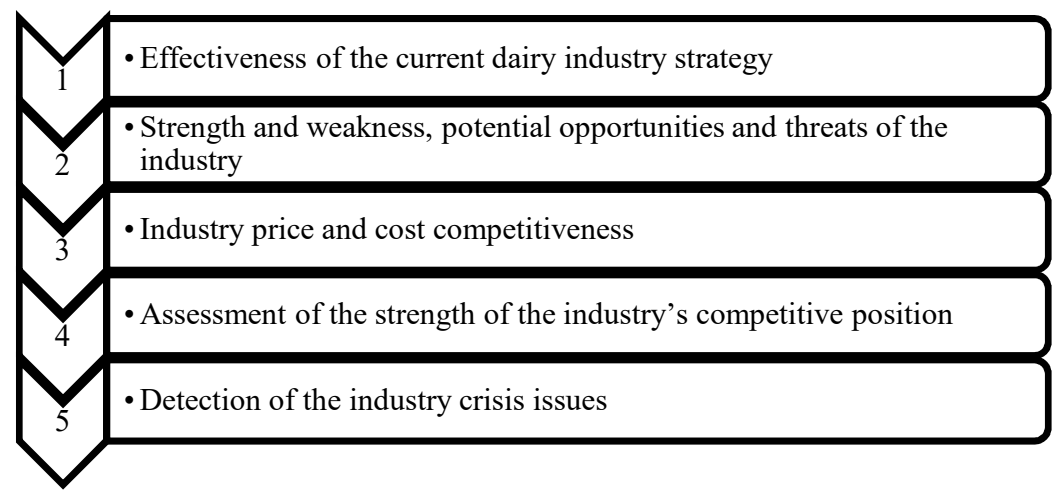

Fig. 1. Principles of Anti-Crisis Strategy, Source: [1].

\section{Materials and method}


Morphological analysis was chosen as a preliminary research method in crisis management, which is an effective methodological approach - a way of seeing and a generalized attitude to reality. Fritz Zwicky [11] proposed to generalize and systematize the concept of morphological research and include in it not only the study of the forms of geometric, geological, biological and generally material structures, but also the study of more abstract structural relationships between phenomena, concepts and ideas, whatever their nature is.

Morphological analysis is based on the concept of a universal connection between all objects, events and spheres of reality. "... in the final and true image of the world, everything is related to everything, and nothing can be discarded a priori as insignificant" [12].

According to this approach, creativity is simply a combination of seemingly different things and parameters, as well as a combination of disparate pieces of information from various areas that are usually not obvious and are not interconnected. Strengths and weaknesses of morphological analysis are systematized in Table 1.

Table 1. Advantages and disadvantages of morphological analysis. Source: [11-12].

\begin{tabular}{|c|c|}
\hline Advantages & Disadvantages and limitations \\
\hline \multirow{2}{*}{$\begin{array}{l}\text { Morphological analysis is a good } \\
\text { structured method and approach that } \\
\text { helps discover new relationships or } \\
\text { configurations that may be skipped by } \\
\text { other - less structured - methods. }\end{array}$} & $\begin{array}{l}\text { The space for solving problems is determined by the } \\
\text { boundaries of the constructed matrix, and the process of } \\
\text { creating a new one takes place inside the morphological } \\
\text { field. }\end{array}$ \\
\hline & $\begin{array}{l}\text { The success of the method directly depends on the } \\
\text { subjective processes of evaluating and selecting key } \\
\text { parameters and the variety of their alternatives and, } \\
\text { ultimately, the most useful combination of them. }\end{array}$ \\
\hline $\begin{array}{l}\text { This method is a power technique for } \\
\text { solving a complex, multidimensional } \\
\text { realistic problem. }\end{array}$ & $\begin{array}{l}\text { The mechanical application of the method leads to the } \\
\text { emergence of a large number of alternatives, many of } \\
\text { which turn out to be meaningless and useless. }\end{array}$ \\
\hline \multirow{2}{*}{$\begin{array}{l}\text { This is a systematic and focused } \\
\text { method that enables systematization } \\
\text { of existing information and generation } \\
\text { of new creative ideas for the design of } \\
\text { new products, technologies and } \\
\text { services. }\end{array}$} & $\begin{array}{l}\text { The absence of criteria for choosing useful combinations } \\
\text { and decision options makes possible the loss of useful } \\
\text { and significant alternatives. }\end{array}$ \\
\hline & $\begin{array}{l}\text { Morphological analysis increases "the probability of } \\
\text { obtaining an interesting solution but does not guarantee } \\
\text { its receipt" [7]. }\end{array}$ \\
\hline \multirow[t]{2}{*}{$\begin{array}{l}\text { Morphological analysis can serve as a } \\
\text { variant of the co-creation of man and } \\
\text { computer. This method can be easily } \\
\text { implemented using computer tools } \\
\text { and can be used in computing, } \\
\text { computer-aided design decisions, } \\
\text { artificial intelligence models, string- } \\
\text { parametric synthesis, parametric } \\
\text { architecture and design. }\end{array}$} & $\begin{array}{l}\text { The combinatorial theory of creativity is only one of the } \\
\text { levels and a partial manifestation of its universal theory, } \\
\text { and the combination is only one of a number of } \\
\text { mechanisms of creative activity. Thus, the understanding } \\
\text { of creativity as a process of creating new combinations } \\
\text { leads to the dominance of convergent thinking over } \\
\text { divergent thinking. In addition, in this method, analytical } \\
\text { and rational thinking prevail over intuitive problem } \\
\text { solving and transforming imagination. }\end{array}$ \\
\hline & $\begin{array}{l}\text { Modern realistic problems are highly variable, uncertain } \\
\text { and ambiguous, and their development scenarios are } \\
\text { often unpredictable and lie beyond certain boundaries of } \\
\text { the morphological space. }\end{array}$ \\
\hline
\end{tabular}

To conduct a morphological analysis, it is necessary to determine the possible parameters that characterize the dairy industry, and approaches that allow formalizing the processes taking place in it. As parameters of the formalized model [13], using ranking methods and economic interpretation, 7 classification groups were identified, including 15 key industry indicators, structured in Figure 2, covering all areas of the dairy industry. 


\begin{tabular}{|c|c|}
\hline Production, thousand tons & $\begin{array}{l}\cdot \mathrm{X} 1 \text { - of milk in farms of all categories } \\
\text {-X2 - of marketable milk }\end{array}$ \\
\hline $\begin{array}{l}\text { Livestock of cows at the } \\
\text { end of the year, thousand } \\
\text { animal units. }\end{array}$ & $\begin{array}{l}\text {-X3 - in farms of all categories at the end of the year } \\
\text {-X4 - in the agricultural organizations, peasant farms, } \\
\text { private subsidiary farms }\end{array}$ \\
\hline $\begin{array}{c}\text { Proportion of brood cows, } \\
\%\end{array}$ & $\begin{array}{l}\text {-X5 - in the agricultural organizations, peasant farms, } \\
\text { private subsidiary farms } \\
\text {-X6 - of milk and mixed production }\end{array}$ \\
\hline $\begin{array}{l}\text { Milk production of cows, } \\
\mathrm{kg} / \text { year }\end{array}$ & $\begin{array}{l}\cdot \mathrm{X} 7 \text { - in farms of all categories } \\
\cdot \mathrm{X} 8 \text { - in agricultural organisations } \\
\cdot \mathrm{X} 9 \text { - in peasant farms } \\
\cdot \mathrm{X} 10 \text { - in private subsidiary farms } \\
\cdot \mathrm{X} 11 \text { - of brood cows }\end{array}$ \\
\hline $\begin{array}{l}\text { Milk and dairy products per } \\
\text { capita, kg/year }\end{array}$ & $\begin{array}{l}\cdot \mathrm{X} 12 \text { - production } \\
\cdot \mathrm{X} 13 \text { - consumption }\end{array}$ \\
\hline Milk processing, tons & -X14 - production of dairy products recalculated as milk \\
\hline Volume of funds, mln. RUR. & -X15 - of state support for the dairy industry \\
\hline
\end{tabular}

Fig. 2. Classification of indicators characterizing the dairy industry. Source: [9, 14-15].

The names proposed for the analysis of the main indicators of the dairy industry, given in Table 2, are available in open sources. The authors assigned their designations for formal description and manipulation in mathematical models. As is customary in most research, indicators were given as the Latin symbol $\mathrm{X}$ and a numeric defining the number in the order located in Table 2.

As the second parameter of the morphological model, we should consider the regions in the order defined in the analysis of the available resources of milk and dairy products. As is customary in most research, the indicators were given as the Latin symbol Y and a numeric defining the number in the order located in Table 3.

Table 3. List of regions of Siberia. Source: [14-15].

\begin{tabular}{|c|l|}
\hline Designation & \multicolumn{1}{c|}{ Region } \\
\hline Y1 & Altai region \\
\hline Y2 & Omsk region \\
\hline Y3 & Novosibirsk region \\
\hline Y4 & Krasnoyarsk region \\
\hline Y5 & Kemerovo region \\
\hline Y6 & Irkutsk region \\
\hline Y7 & Tomsk region \\
\hline Y8 & Republic of Khakassia \\
\hline Y9 & Republic of Altai \\
\hline Y10 & Republic of Tuva \\
\hline
\end{tabular}

Morphological analysis of the parameters of the dairy industry (Table 2) by region (Table 3) covers all options, creating a decision field (15 by 10) out of 150 possible combinations. In addition, each of these combinations is evaluated by the rating (place) of 
the region according to the indicator under study, which characterizes the level of depressiveness of the region. The higher the rating, the higher the region's depression.

\section{Research results}

Based on the analysis, a morphological matrix was formed (Table. 4).

Table 4. Morphological matrix of ranking of Siberian regions by indicators of the dairy industry. Source: [14-15].

\begin{tabular}{|c|c|c|c|c|c|c|c|c|c|c|}
\hline Designation & Y1 & Y2 & Y3 & Y4 & Y5 & Y6 & Y7 & Y8 & Y9 & Y10 \\
\hline $\mathrm{X} 1$ & 1 & 4 & 3 & 2 & 6 & 5 & 8 & 7 & 9 & 10 \\
\hline $\mathrm{X} 2$ & 1 & 3 & 2 & 4 & 6 & 5 & 7 & 9 & 8 & 10 \\
\hline X3 & 1 & 4 & 2 & 3 & 8 & 6 & 10 & 7 & 5 & 9 \\
\hline $\mathrm{X} 4$ & 1 & 3 & 2 & 4 & 8 & 6 & 9 & 7 & 5 & 10 \\
\hline $\mathrm{X} 5$ & 7 & 4 & 5 & 1 & 6 & 3 & 2 & 8 & 9 & 10 \\
\hline X6 & 7 & 4 & 5 & 1 & 6 & 2 & 3 & 8 & 9 & 10 \\
\hline $\mathrm{X} 7$ & 3 & 6 & 5 & 2 & 4 & 7 & 1 & 8 & 9 & 10 \\
\hline $\mathrm{X} 8$ & 3 & 6 & 5 & 2 & 4 & 7 & 1 & 8 & 9 & 10 \\
\hline X9 & 3 & 6 & 5 & 2 & 4 & 7 & 1 & 8 & 9 & 10 \\
\hline $\mathrm{X} 10$ & 3 & 6 & 5 & 2 & 4 & 7 & 1 & 8 & 9 & 10 \\
\hline $\mathrm{X} 11$ & 3 & 6 & 5 & 2 & 4 & 7 & 1 & 8 & 9 & 10 \\
\hline $\mathrm{X} 12$ & 1 & 5 & 2 & 7 & 8 & 9 & 4 & 6 & 3 & 10 \\
\hline $\mathrm{X} 13$ & 1 & 5 & 2 & 7 & 8 & 9 & 4 & 6 & 3 & 10 \\
\hline $\mathrm{X} 14$ & 1 & 2 & 5 & 3 & 4 & 6 & 8 & 7 & 9 & 10 \\
\hline $\mathrm{X} 15$ & 1 & 3 & 2 & 4 & 5 & 6 & 7 & 8 & 9 & 10 \\
\hline Total points & 37 & 67 & 55 & 46 & 85 & 92 & 67 & 113 & 114 & 149 \\
\hline $\begin{array}{l}\text { Region } \\
\text { rating }\end{array}$ & 1 & 4 & 3 & 2 & 6 & 7 & 5 & 8 & 9 & 10 \\
\hline $\begin{array}{l}\text { State of the } \\
\text { regions }\end{array}$ & \multicolumn{2}{|c|}{ promising } & \multicolumn{2}{|c|}{ positive } & \multicolumn{2}{|c|}{ stable } & \multicolumn{2}{|c|}{ pre-depressive } & \multicolumn{2}{|c|}{ depressive } \\
\hline $\begin{array}{c}\text { Point } \\
\text { interval }\end{array}$ & \multicolumn{2}{|c|}{$\begin{array}{c}\text { Less than } \\
30 \\
\end{array}$} & \multicolumn{2}{|c|}{$\begin{array}{c}\text { From } 31 \text { to } \\
60\end{array}$} & \multicolumn{2}{|c|}{ From 61 to 90} & \multicolumn{2}{|c|}{$\begin{array}{c}\text { From } 91 \text { to } \\
120\end{array}$} & \multicolumn{2}{|c|}{$\begin{array}{c}\text { More than } \\
121\end{array}$} \\
\hline $\begin{array}{l}\text { Number of } \\
\text { regions in } \\
\text { the interval }\end{array}$ & & & & \multicolumn{2}{|c|}{3} & \multicolumn{2}{|c|}{ 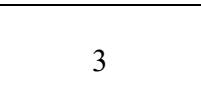 } & \multicolumn{2}{|c|}{1} \\
\hline \multirow{3}{*}{ Regions } & & & \multicolumn{2}{|c|}{$\begin{array}{l}\text { 1.Altai } \\
\text { region }\end{array}$} & \multicolumn{2}{|c|}{ 2.Omsk region } & \multicolumn{2}{|c|}{$\begin{array}{l}\text { 6.Irkutsk } \\
\text { region }\end{array}$} & \multicolumn{2}{|c|}{$\begin{array}{l}\text { 10.Republic } \\
\text { of Tuva }\end{array}$} \\
\hline & & & \multicolumn{2}{|c|}{$\begin{array}{l}\text { 4.Krasnoyar } \\
\text { sk region }\end{array}$} & \multicolumn{2}{|c|}{$\begin{array}{l}\text { 7.Tomsk } \\
\text { region }\end{array}$} & \multicolumn{2}{|c|}{$\begin{array}{l}\text { 8. Republic of } \\
\text { Khakassia }\end{array}$} & & \\
\hline & & & \multicolumn{2}{|c|}{$\begin{array}{l}\text { 3.Novosibir } \\
\text { sk region }\end{array}$} & \multicolumn{2}{|c|}{$\begin{array}{l}\text { 5.Kemerovo } \\
\text { region }\end{array}$} & \multicolumn{2}{|c|}{$\begin{array}{l}\text { 9.Republic of } \\
\text { Altai }\end{array}$} & & \\
\hline
\end{tabular}

As a result of the morphological analysis, 5 clusters of the state of the regions were formed. Not a single region fell into a promising cluster, three regions were included into a positive, stable, and pre-depression cluster, and only one region was classified as depressed - this is the Republic of Tuva.

Significant discrepancies in the results of assessments of resource potential and morphological analysis should be noted. The common in their assessments was the unconditional first place of the Altai Territory, the third place of the Novosibirsk Region and the last three places of the Republics of Khakassia, Altai and Tuva. 


\section{Discussion of research results}

An example is the crisis in the dairy industry of the depressed regions of the Russian Federation, which threatens a person's comfortable existence and his health. For example, the Republic of Tuva in terms of per capita consumption of dairy products is almost two times less than the permissible norm [14-15]. This leads to seeking new production technologies which, in modern conditions, are primarily digital. Today, there is a problem of inefficient management at dairy enterprises in depressed regions, which has become the most common among those that impede the normal effective development of market relations.

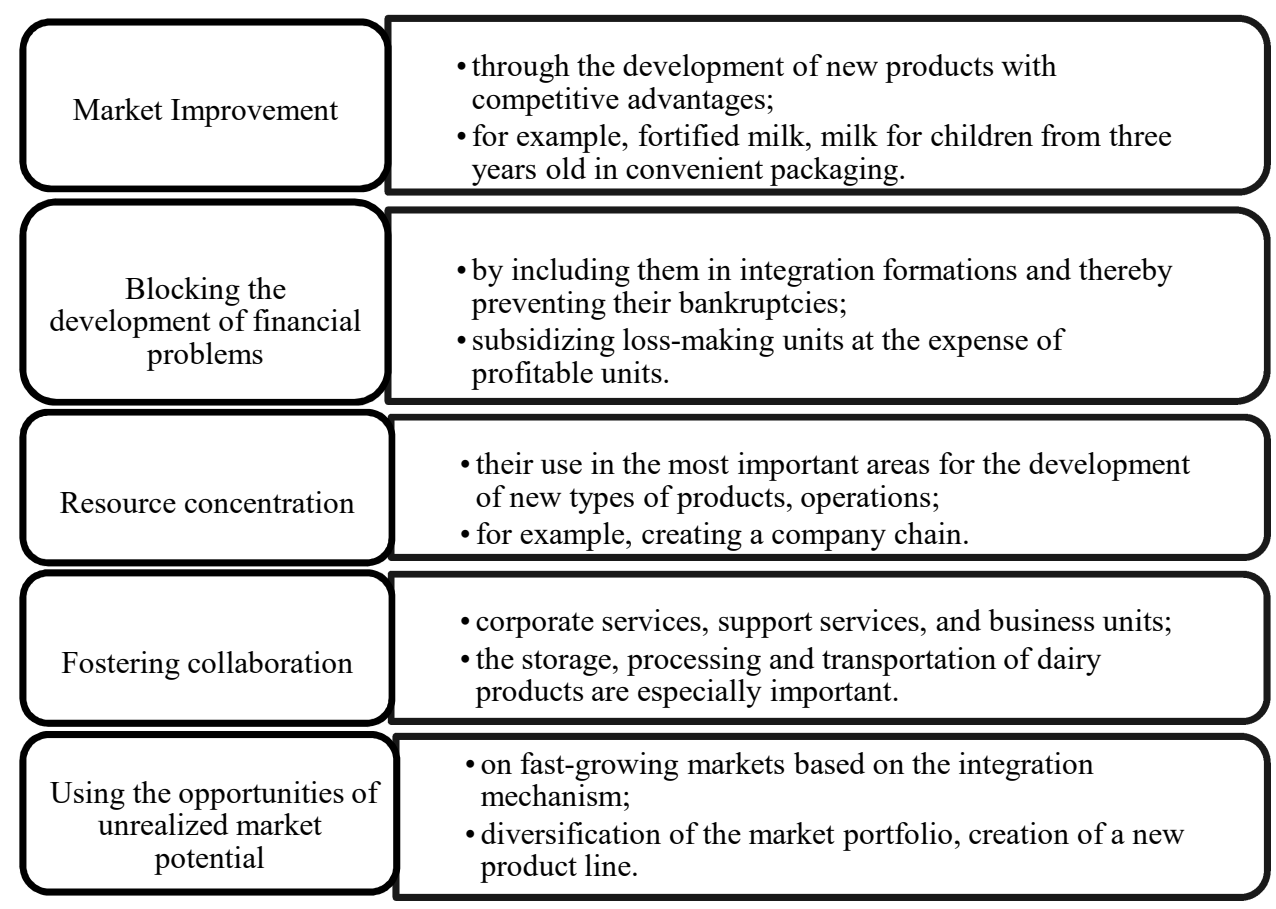

Fig. 3. Strategic opportunities of reorganization, Source: [1].

The subject of crisis management are realistic problems and factors of the crisis emergence (Fig. 3), in other words, all manifestations of contradictions that can provoke an aggravation of the situation and lead to a crisis. The process of any management assumes the presence of features of crisis management in it.

By the crisis management function is meant a certain type of activity that implements the subject of crisis management and determines its final result. This activity answers the logical question: what needs to be done so that the management process is successful at all stages of the crisis.

The main feature of crisis management is its integration in the conditions of formal and informal management. In addition, of great importance for crisis management is its focus on the future, availability of the opportunity to form a rational "strategy for the long-term development of the dairy industry" [16], a structured version of which is shown in Figure 2. "The anti-crisis strategy of dairy organizations is connected with the use of rehabilitation opportunities for vertical integration and diversification of the assortment, as well as the development of innovative products" [5]. 


\section{Conclusion}

The introduction of digital technologies and the organization of automated workstations based on them are recommended as effective tools for crisis management, which will compensate for the shortage of qualified personnel and increase labor productivity. At the same time, the need for state support and attracting investors will increase [1].

\section{Acknowledgment}

The article was prepared with the financial support of the Novosibirsk State Technical University (project C19-12).

\section{References}

1. M.K. Chernyakov, M.M. Chernyakova, I.A. Chernyakova, Advances in Economics, Business and Management Research: New Silk Road: Business Cooperation and Prospective of Economic Development (NSRBCPED 2019) 131, 16-23 (2020) DOI: 10.2991/aebmr.k.200324.004

2. A.A. Kuzin, N.A. Medvedeva, K.A. Zadumkin, Economic and social changes-facts trends forecast 11(6), 73-88 (2018) http://esc.vscc.ac.ru/article/28020?

3. Rabobank. Food \& Agri Home. Sectors. Dairy https://research.rabobank.com/far/en/sectors/dairy/index.html\#sort=\%40farcreated $\% 20$ descending

4. Top Milk Producing Countries (2020) https://www.worldatlas.com/articles/top-cowsmilk-producing-countries-in-the-world.html

5. M.K. Chernyakov, M.M. Chernyakova, IOP Conference Series: Materials Science and Engineering 656, 012014 (2019) DOI: 10.1088/1757-899X/656/1/012014

6. D.J. Deasy, International journal of dairy technology 55(1), 1 (2002) doi.org/10.1046/j.1364-727X.2001.00036.x

7. A. Popescu, Scientific papers-series management economic engineering in agriculture and rural development 17(2), 281-289 (2017)

8. J. Falkowski, British Food Journal 117(10), 2465-2483 (2015) doi.org/10.1108/BFJ12-2014-0433

9. C. Karelakis, Z. Abas, K. Galanopoulos et al., Agron. Sustain. Dev. 33, 445-456 (2013) https://doi.org/10.1007/s13593-013-0136-y

10. M.K. Chernyakov, M.M. Chernyakova, K.C. Akberov, Advances in Engineering Research. Actual issues of mechanical engineering, AIME 2018 157, 124-128 (2018) DOI: 10.2991/aime-18.2018.24

11. F. Zwicky, Discovery, Invention, Research - Through the Morphological Approach (The Macmillan Company, Toronto, 1969)

12. S. Markov, Morphological analysis, Activating Creativity https://geniusrevive.com/en/morphological-analysis/

13. M.K. Chernyakov, M.M. Chernyakova, K.Ch. Akberov, Advances in Social Science, Education and Humanities Research. SICNI 2018 240, 562-567 (2019) DOI: 10.2991/sicni-18.2019.114

14. M.K. Chernyakov, M.M. Chernyakova, Advances in Economics, Business and Management Research: International Scientific and Practical Conference on Digital 
Economy (ISCDE 2019) 105, 284-289 (2019) DOI: https://dx.doi.org/10.2991/iscde19.2019.54

15. M.K. Chernyakov, M.M. Chernyakova, Advances in Social Science, Education and Humanities Research, 5 International Conference on Social, Economic, and Academic Leadership (ICSEALV 2019) 386, 221-227 (2019) DOI: 10.2991/assehr.k.191221.035

16. M.K. Chernyakov, M.M. Chernyakova, K.C. Akberov, Advances in Economics, Business and Management Research. Modern Management Trends and the Digital Economy: from Regional Development to Global Economic Growth (MTDE 2019) 81, 373-378 (2019) DOI: $10.2991 /$ mtde-19.2019.71 